\title{
Judith Davey
}

\section{Age Discrimination in the Workplace}

Age discrimination is often cited as a barrier to participation in work by older people, and the workplace provides the most common grounds for complaints of this nature. Age discrimination predominantly affects older rather than younger groups (although the latter are not exempt), and is often based on myths and stereotyped attitudes about older people and older workers which can be easily refuted (Davey, 2007; Alpass and Mortimer, 2007; Gray and McGregor, 2003). Age discrimination as an issue in the workplace is not new. It was well documented in Janice Burns' literature review on mature workers for the Department of Work and Income in 2001 (Burns, 2001) and by Justina Murray in her review of age discrimination in employment, commissioned by the New Zealand Human Rights Commission in 2002 (Murray, 2002). In 2006 the EEO Trust's Work and Age Survey Report showed that $31 \%$ of respondents had experienced age discrimination at work (EEO Trust, 2006).

Judith Davey is a Senior Associate of the Institute for Governance and Policy Studies and was formerly Director of the New Zealand Institute for Research on Ageing. Her main research focus is the policy implications of population ageing.
Age discrimination pervades the entire employment relationship and can take a variety of forms. It occurs in relation to promotion, job allocation, salary differentials, access to training and staff benefits (for example, cut-off ages for life assurance cover and long service leave). General attitudes, as well as inter-staff action such as bullying and exclusion from social activities, can also disadvantage older workers (OGC Consulting, 2013). Age discrimination is noted particularly in recruitment (Australian Human Rights Commission, 2010). Recruitment agents have been shown to apply age biases in deciding who to put forward for jobs. Bennington and Wein (2003) talked about 'collusion' between recruitment agencies, human resource staff and managers in Australia, allowing discrimination to continue. Older workers may face particular difficulties when they seek to re-enter the workforce after redundancy or an absence for other reasons, including elder care (National Seniors Productive Ageing Centre, 2012).

Why does age discrimination happen? Murray's review typified age discrimination in the workplace as the tendency to 
stereotype and generalise about attributes, skills and abilities on the basis of age and to use these stereotypes and generalisations to inform human resources practice (Murray, 2002). Other explanations include the use of age as a quick and cheap proxy for merit assessments; remuneration practices based on seniority; social and corporate preference for youth; and a tendency for younger managers to recruit people like themselves. OGC Consulting (2013, p.31-2) asked candidates for employment in New Zealand: 'what do you think are the key causes of age-related discrimination?' The responses reflected Murray's list but also focused on interrelationships between age groups in the workplace, lack of understanding between generations, and a lack of exposure to or experience of working with different ages.

\section{Is age discrimination in the} workplace a problem?

As recognition of the challenges of population ageing and the benefits of prolonging workforce participation grows, governments in many developed countries are adopting policies to increase labour force participation by older people (Beard et al., 2012). This is on the basis of benefits for society and the economy. Demographic trends suggest that labour and skills shortages will become more pressing as younger people entering the workforce do not balance the numbers retiring. There are social and economic benefits from having an economically active older population. It will contribute to economic growth and the maintenance of living standards and also, through taxation, help to meet the costs of an ageing population. Prolonging workforce participation will also be good for business, which will face competition for skilled workers, raising the cost of labour. For individuals, longer lives and better health in later life provide opportunities for prolonging workforce participation. There is considerable evidence that participation in meaningful and appropriate work is beneficial to the physical, psychological and financial well-being of older people (Hinterlong, Morrow-Howell and Rozario, 2007; Ford and Orel, 2005; Jaworski, 2005). In other words, it is part of active ageing, and age discrimination is a barrier to achieving

these desirable objectives.

The New Zealand Positive Ageing Strategy further stresses these benefits, describes older people as a 'valuable resource' and endorses policies that support 'productive lives in the economy and society' (Dalziel, 2001). If older people are unable to contribute their full economic capacity due to discrimination, their productivity as workers will fall below potential; they will be contributing less as taxpayers and may be dependent on welfare benefits. At the personal level, they will be less able to set themselves up financially for their old age and they may lack the positive sense of social inclusion and contribution which can be derived from high-quality work.

\section{... it is sometimes unclear whether there is real age discrimination or if decisions made by employers simply reflect the drawbacks of older workers in terms of their physical and mental capacities, outdated skills and lack of ability with new technology.}

\section{Findings from the Active Ageing project}

Making Active Ageing a Reality is a research project undertaken through the University of Waikato, funded by the Ministry of Business, Innovation and Employment. Objective 2 refers to the contribution of older people through participation in the paid workforce. The aim is to identify practices and policies which either encourage or discourage older people's participation in paid work, referring in particular to participation from age 65 . It incorporates a review of relevant New Zealand and overseas academic, policyrelated and business literature. In mid2013 interviews were carried out with 33 employers and 26 key informants in Auckland, Hamilton, Wellington and Christchurch. The employers came from a range of industries, with workforces ranging from under ten to several thousand. The key informants represented professional, commercial, trade union and public sector organisations involved in labour market issues and policies.

Both groups were asked about age discrimination as a possible obstacle for older people in the workplace. The majority agreed that it can be a barrier, although some were unsure and some considered that it was less prevalent than previously. Some thought that discrimination would become less obvious as the labour market tightens due to demographic change or as 'the victims and perpetrators of age discrimination themselves age'. ${ }^{1}$

There was an impression that much age discrimination is not overt and may even be unrecognised. 'Sometimes people don't know they are doing it. They employ people like themselves who they 
at which recruitment firms replied that they simply offer what is palatable to employers.

The respondents suggested that it is sometimes unclear whether there is real age discrimination or if decisions made by employers simply reflect the drawbacks of older workers in terms of their physical and mental capacities, outdated skills and lack of ability with new technology. 'When you can't do things because of your age, the individual might see this as discrimination.' 'Stereotypes exist for a reason, as a result of people's negative experiences.' It is difficult to see what
Many employers are concerned about how to terminate the contracts of nonperforming employees without risk, in the absence of compulsory retirement. Murray (2002, p.40) described compulsory retirement as one of the most institutionalised and prevalent forms of age discrimination. It was banned in New Zealand by legislation in 1993 which became effective from February 1999. This was supported by the New Zealand Employers' Federation: 'The demise of compulsory retirement should not be seen as a difficulty to be surmounted but as an opportunity to think again about how the

\section{Early statements by the [Australian] human rights and equal opportunity commissioner ... on the valuing of older workers as not only a human rights issue but also part of good business practice ...}

proportion of this reflects preconceptions about older people as opposed to genuine performance concerns. Some thought that older workers may disadvantage themselves by their attitudes and by feeling that they should make way for younger workers.

A particular concern for employers is their need to start planning for the retention of skills or the phasing out of workers, according to their business requirements and the ease or otherwise of replacing skills and experience. To do this successfully and efficiently requires employers to know about the retirement intentions of their workers. This, in turn, needs 'honest conversations' between employers and employees - 'for the employee to sit down with their employer (to discuss retirement or "staying on" intentions) without feeling that their employment is put at risk - this can be an incentive not to have the conversation'. These conversations are often avoided by employers, on their part, for fear of opening themselves to an accusation of discrimination or constructive dismissal. There was clear recognition that such conversations could be tricky and potentially misunderstood by employees. process of retirement can be managed' (New Zealand Employers' Federation, 1998, p.14). Some employers still suggest that a fixed retirement age would be beneficial to deal with difficult cases. 'It is tricky with under-performance. HR used to say - wait till they retire - but now this is not an option.' The process has to be done well to maintain the integrity and good name of the firm and to avoid accusations of discrimination. It may, however, involve challenges for managers and requires good performance reviews throughout the working life of each staff member. This may be difficult in small workplaces. But, as one respondent concluded, 'It would be a poor business if it waited for a specific age to rid itself of poor performing employees and it didn't manage poor performance.'

\section{So what can be done about age} discrimination?

\section{Formal policy and legislation}

As Leeson (2006, p.12) said:

Liberal democracies have been much slower in acknowledging the unfairness of age discrimination than they have been in squaring up to discrimination on grounds of race or sex. Unfavourable treatment of the young and the old has been persistently justified by appeal to its social utility.

But now demographic and market trends, especially the tightening in labour supply, are forcing advanced economies to recognise that such attitudes threaten to undermine their sustainability. This has emerged from the dominance of economic rhetoric rather than any discussion of social or moral responsibility (Riach, 2006, p.553). However, it cannot be assumed that market forces by themselves will make the necessary adjustments. Legislation to ban age discrimination has been enacted in many countries, including the United States, Australia, Canada, New Zealand, Ireland, Finland, Germany, the Netherlands and Japan (Taylor, 2002). Under Council Directive 2000/78/EC of 27 November 2000, member states of the European Union were required to have legislation in place by the end of 2006 to make age discrimination in employment and vocational training unlawful. ${ }^{2}$

In the US, the federal Age Discrimination in Employment Act (ADEA) has been in effect since 1968 (OECD, 2006, p.108). The original act prohibited discrimination on the basis of age for those aged 40 to 65 . Subsequent amendments raised the upper age limit to 70 and then eliminated it altogether, ending mandatory retirement for nearly all workers.

In Australia, compulsory retirement was abolished in the commonwealth public service in 2001. The federal Age Discrimination Act was passed in 2004, the Fair Work Act in 2009, and there are relevant provisions in the individual states. Early statements by the human rights and equal opportunity commissioner (FitzPatrick, 1999) on the valuing of older workers as not only a human rights issue but also part of good business practice were echoed in 2012 by the age discrimination commissioner, Susan Ryan (Ryan, 2012). She called age discrimination a waste of human resources and a threat to the competitiveness and growth of Australian business. 
In the UK the Equality Act 2010 codified numerous acts and regulations which formed the basis of antidiscrimination law. This legislation has the same goals as the EU directives, whose provisions it mirrors and implements. It requires equal treatment in access to employment as well as private and public services, regardless of the protected characteristics, which include age. Previously, regulations which came into effect in 2006 made it illegal for an employer to force anyone to retire on the grounds of age before they were 65 and gave employers a duty to consider requests from employees who wished to work after this age. So long as employers followed procedures for informing and consulting employees, they could compulsorily retire them at 65 on business grounds but not on the grounds of age alone (Metcalf and Meadows, 2010; CROW, 2005). This was seen as effectively giving employers a 'get out of jail free' card. The default retirement age in the UK was fully abolished under the Employment Equality (Repeal of Retirement Age Provisions) Regulations 2011.

In New Zealand the Human Rights Act (HRA) came into effect in February 1999. Section 22 forbids employers from discriminating against suitably qualified job applicants on a number of grounds, including age. Its provisions apply to all aspects of employment - recruitment, selection, remuneration, training, promotion, transfers, retirement and termination - and outlawed compulsory retirement. $^{3}$

\section{How effective is legislation in combatting discrimination in the workforce?}

There is controversy in the literature about how effective the long-standing ADEA in the United States has been, with the conclusion that it has boosted employment rates for workers aged 60 plus by reducing unlawful terminations, but does not appear to have encouraged many employers to hire such workers (Johnson, 2008; Neumark, 2009). The enforcement of the ADEA has focused on terminations much more than hiring. There are often difficulties in establishing that age discrimination has occurred and evidence suggests continued discrimination against older people in hiring and other employment-related decisions, such as promotions. Other criticisms of the ADEA are that it benefits older workers at the expense of other workers, and that it has unintended consequences, such as acting as a deterrent to employ older workers who cannot be fired without litigation.

In the UK, Metcalf and Meadows (2010) reported on surveys of employers before and after the new enactments. They found some progress, signalling a more objective approach, less explicit use of age in the recruitment process and less likelihood of discrimination. However,
(2001, p.40-41) found that 39\% of 1012 employers did not believe that the HRA was working and most felt that the legislation was ineffective in preventing age discrimination in recruitment. Many believed that employers should have free choice in employing staff; that the labour market should be left to its own devices. Later, Wood, Harcourt and Harcourt (2004) reviewed the HRA and found widespread non-compliance. They linked ongoing age discrimination to labour legislation which relies on individual litigation for enforcement. In her submission to the retirement

\section{Critics of anti-age discrimination legislation believe that it does not change employers' behaviour, but simply leads to more subtle and covert ways of discriminating, sending employment ageism 'underground'.}

the improvements for older workers were found mainly in larger establishments and the public sector. Flynn also found that employers were mainly guided by short-term market pressures, leaving aside equality goals (Flynn, 2010). Managers often spoke favourably about older workers and generally did not resist retaining workers aged 65 plus if they could contribute human capital and company-specific knowledge, but none had formalised a process of considering requests except for public sector organisations. Flynn concludes that the 'business case' approach in the UK had a limited impact on employers' practices and was a weak instrument for changing the retirement culture.

In New Zealand also, despite being effective in outlawing compulsory retirement the 1993 legislation did not appear to have an immediate effect on the prevalence of age discrimination. In EEO Trust research, $42 \%$ of employers said that the legislation had had no influence and $42 \%$ some or a little (White, 1999). The influence was more likely to have been felt in larger firms. McGregor commissioner's 2007 review of retirement income policy, McGregor (2007) also found shortcomings, commenting that the legislation is predicated on individual complaints and this makes it harder to address systemic ageism.

Critics of anti-age discrimination legislation believe that it does not change employers' behaviour, but simply leads to more subtle and covert ways of discriminating, sending employment ageism 'underground'. In the international sphere, Leeson (2006) found that age accounts for only a small number of employment discrimination complaints and the majority of claims are dismissed. In many jurisdictions a higher prevalence of discrimination is found in populationbased surveys than among formal complaints (McGregor, 2007). In recent years only $2 \%$ of complaints to the New Zealand Human Rights Commission on the basis of discrimination in employment have been made by people aged 65 plus (overall, around $38 \%$ of complaints are employment-related and $11 \%$ are on the grounds of age discrimination in all areas). ${ }^{4}$ This is because of worker 
ignorance of the complaints procedure and lack of trust, of feelings that the incidents are not serious enough and fears about job security, especially for lower-paid and lower-status workers. The bases for complaints in New Zealand have been: declined job due to age; detrimental treatment because of age; dismissed or threatened with dismissal because of age; and forced retirement at age 65. Thus, despite the passing of this legislation, there is evidence, from both the New Zealand and international evidence, that it has far from extinguished something about it. Nevertheless, several felt that the HRA was too easy to get around. There were calls for the law to be brought up to date, to be clearer and more specific.

There may be scope for tightening up and clarifying anti-discrimination legislation and for using other employment law in this context. Suggestions arising in the interviews included use of the Employment Court and the inclusion of anti-discrimination measures in industrial agreements. Another suggestion was to add good

\section{Legislation against age discrimination has been enacted in several countries but has had limited success because of the difficulty of identifying age discrimination, because much if it is not overt, and discriminatory practices are deepseated in business culture.}

age discrimination in the workforce.

In the Active Ageing research, key informants and employers were asked how they thought the New Zealand anti-discrimination legislation was working and if they saw the need for any changes or improvements. Few of either group could suggest concrete improvements and there was a general view that the legislation is working well as far as it can, given the difficulty of defining age discrimination and the fact that much of it is covert. Several agreed that if penalties were increased, 'this would send the behaviour underground; it is very complex cultural and social behaviour'. 'We should make (the law) more consultative and participative and less regulatory. Law doesn't solve things; people need reasons for doing things.' They agreed that legislation is needed as a sanction and as a normative statement that age discrimination is not to be tolerated. 'Need traffic rules to deal with worst cases, but law is not a solution.' Many employers had no experience of using the HRA related to age, although most knew employer and EEO requirements to the Employment Relations Act 2008..$^{5}$ Good employer provisions currently apply only in the state sector, through the Crown Entities Act 2004, the State Sector Act 1998 and the Local Government Act 2002, but these provisions do not encompass age (only women, Māori and people with disabilities are specifically mentioned) (McGregor, 2006). Could good employer provisions, including measures against age discrimination, be extended to the private sector in New Zealand? Should the onus be on employers to show that their hiring practices are not discriminatory? The counterargument, from business, suggests that further and tighter regulation would slow down the economy and overload employers with compliance costs.

\section{What other measures are possible?}

Although legislation can have educative effects, the Australian Human Rights and Equal Opportunity Commissioner concluded that 'age-based stereotypes must be addressed by education and information as well as law and policy'
(FitzPatrick, 1999). Many of the Active Ageing interviewees agreed with this conclusion. They called for research to document discrimination and publicity to be given to age discrimination cases which have been successfully prosecuted. 'We almost need a court case to put the wind up employers.' Such information could be used by government, as well as other agencies, to advocate and educate employers and their organisations on the value of older workers and the benefits of employing them. To encourage less discriminatory thinking would require a concerted effort: 'Not just a couple of commercials.' Other agencies mentioned which might have a role included Age Concern, the Human Rights Commission, ${ }^{6}$ the New Zealand Institute of Management, Business New Zealand, chambers of commerce, employers' associations and the Council of Trade Unions. But several felt that the movement to raise awareness of age discrimination and to seek change has to be led by government agencies. One respondent called for an age discrimination commissioner alongside the EEO commissioner, as there is in Australia.

There was a call for 'champions' working against age discrimination within the business community, as well as in the older workforce itself. A role was seen for human resource managers (and the Human Resources Institute) as educators and enablers, with the potential to educate younger managers. The preponderance of businesses employing fewer than 25 people, often without professional HR services, increases the challenge. Public education could also help, with a role for government in this area, to educate employers on the benefits of non-discriminatory processes and to model such provisions in all public sector agencies.

There is no lack of good practice guides for employers relating to the employment of older workers, with case studies of employers who have harnessed business benefits in an age-diverse workforce. In New Zealand these have been produced by the Equal Employment Opportunities Trust (1999), the New Zealand Employers' Federation (1998) and the New Zealand Human Rights Commission (2008). 
Overseas examples include publications by the UK Department of Work and Pensions (2013), Naegele and Walker (2006), Manpower Inc. (2007) and Finkelstein, Roher and Owusu (2013).

\section{Conclusion}

Prolonging workforce participation by older people is supported for social, economic and business reasons and is becoming a policy objective in many developed countries. Increased participation, even at age 65 plus, is becoming a reality and this is reflected in the New Zealand trends, but there are still barriers. Age discrimination is one of these. Legislation against age discrimination has been enacted in several countries but has had limited success because of the difficulty of identifying age discrimination, because much if it is not overt, and discriminatory practices are deepseated in business culture. These issues apply also in wider society, which makes it even more difficult to combat discriminatory attitudes. Measures against age discrimination in the workplace will require more than legislation, although legislation has its place as a sanction and as a signal to society that such behaviour is not to be tolerated. Legislation must be supported by other policies - public education and information, aimed at employers but also at the rest of society, showing the benefits of prolonging workforce participation, providing it is well planned, well managed and suits the needs of older people. In doing this there is a role for government, but also for the business community itself and for civil society.

\footnotetext{
Quotations in the text are from the verbatim recordings of interviews, but are not attributed, to preserve confidentiality.

2 http://eur-lex.europa.eu/LexUriServ/LexUriServ.do?uri=CELEX :32000L0078:EN:HTML, accessed 12 March 2014.

3 In these areas age discrimination can affect younger workers. Between 2002 and 2006 nearly 40\% of age discrimination enquiries and complaints to the Human Rights Commission were from employees aged 40 or under.

4 Recent data kindly provided by the New Zealand Human Rights Commission, Auckland.

5 The Employment Relations Act's good faith requirements are relevant to human resource strategic plans and bargaining strategies in particular, but not to EEO or good employer provisions. http://live.isitesoftware.co.nz/neon2012/ adviceandguidance/crownentitiesadvice/, accessed 12 March 2014.

6 The Human Rights Commission has produced material for employers and workers which sets out the legal requirements and outlines best practice.
}

\section{References}

Alpass, F. and R. Mortimer (2007) Ageing Workforces and Ageing Occupations: a discussion paper, Wellington: Department of Labour

Australian Human Rights Commission (2010) Age Discrimination: exposing the hidden barrier for mature age workers, Sydney: Australian Human Rights Commission

Beard, J.R., S. Biggs, D. Bloom, L. Fried, P. Hogan, A. Kalache and S.J. Olshansky (eds) (2012) Population Ageing: peril or promise, Geneva: World Economic Forum

Bennington, L. and R. Wein (2003) 'Does the resume open the door to age discrimination for older workers?', Australasian Journal of Ageing, 22 (2), pp.70-5

Burns, J. (2001) Literature Review on Mature Workers Programme, Wellington: Top Drawer Consultants for Department of Work and Income

CROW (2005) The New Law on Age Discrimination: how prepared are employers?, Centre for Research into the Older Workforce briefing paper 5, Guildford: University of Surrey

Dalziel, L. (2001) The New Zealand Positive Ageing Strategy, Wellington: Senior Citizen's Unit, Ministry of Social Policy

Davey, J. (2007) Maximising the Potential of Older Workers (revised edn), Wellington: New Zealand Institute for Research on Ageing

Department of Work and Pensions (2013) Employing Older Workers: an employer's guide to today's multi-generational workforce, London: Department of Work and Pensions

EEO Trust (1999) Benchmark Your Workplace Progress on Age, Auckland: Equal Employment Opportunities Trust

EEO Trust (2006) EEO Trust Work and Age Survey Report, Auckland: Equal Employment Opportunities Trust

Finkelstein, R., S. Roher and S. Owusu (2013) Age Smart Employer, NYC: compendium of strategies and practices, New York: New York Academy of Medicine

FitzPatrick, K. (1999) Anti-discrimination Legislation and the Older Worker, Sydney: Australian Human Rights Commission

Flynn, M. (2010) 'The United Kingdom government's "business case" approach to the regulation of retirement', Ageing and Society, 30 (3), pp.421-43
Ford, R. and N. Orel (2005) 'Older adult learners in the workforce', Journal of Career Development, 32 (2), pp.139-52

Gray, L. and J. McGregor (2003) 'Human resource development and older workers: stereotypes in New Zealand', Asia Pacific Journal of Human Resources, 41 (3), pp.338-53

Hinterlong, J., N. Morrow-Howell and P. Rozario (2007) 'Productive engagement and late life physical and mental health: findings from a nationally representative panel study', Research on Aging, 29 (4), pp.348-70

Jaworski, B. (2005) 'Aging workers, changing value', Journal of Employee Assistance, 1st Quarter, pp.22-3

Johnson, R. (2008) 'Employment opportunities at older ages: introduction to the special issue', Research on Aging, 31 (3), pp.3-16

Leeson, G. (2006) 'The Employment Equality (Age) Regulations and beyond', Ageing Horizons, 5, pp.12-19

McGregor, J. (2001) Employment of the Older Worker, Palmerton North: Massey University

McGregor, J. (2006) The Good Employer: getting it right: guidance from the equal employment opportunities commissioner, Wellington: Human Rights Commission

McGregor, J. (2007) Employment of Older Workers: submission to the retirement commissioner's 2007 review of retirement income policy, Wellington: Human Rights Commission

Manpower Inc. (2007) The New Agenda for an Older Workforce, Milwaukee: Manpower Inc.

Metcalf, H. and P. Meadows (2010) Second Survey of Employers' Policies, Practices and Preferences Relating to Age, employment relations research series, 110, London: Department for Work and Pensions and Department for Business Innovation and Skills

Murray, J. (2002) Age Discrimination in Employment: a review, Research and Information Manager, EEO Trust, for the New Zealand Human Rights Commission, Auckland: Equal Employment Opportunities Trust Naegele, G. and A. Walker (2006) A Guide to Good Practice in Age Management, Dublin: European Foundation for the Improvement of Living and Working Conditions

National Seniors Productive Ageing Centre (2012) Barriers to Mature Age Employment: final report of the consultative forum on mature age 
participation, report prepared on behalf of the Consultative Forum on Mature Age Participation, Canberra: National Seniors Productive Ageing Centre

Neumark, D. (2009) 'The Age Discrimination in Employment Act and the challenge of population aging', Research on Aging, 31 (1), pp.41-68

New Zealand Employers' Federation (1998) Employment of Older

Employees and Retirement: a guide for employers, Wellington: New Zealand Employers' Federation

New Zealand Human Rights Commission (2008) Valuing Experience: a practical guide to recruiting and retaining older workers, Wellington: New Zealand Human Rights Commission

OECD (2006) Live Longer, Work Longer, Paris: OECD

OGC Consulting (2013) Coming of Age: the impact of an ageing workforce on New Zealand business, Wellington and Auckland: OGC Consulting
Riach, K. (2006) 'Older workers: learning from three international experiences', Social Policy and Society, 5 (4), pp.551-63

Ryan, S. (2012) Age Discrimination: a waste of human resources, speech to Human Resources Directors Networking Forum, March, retrieved from www.humanrights.gov.au

Taylor, P. (2002) New Policies for Older Workers, Joseph Rowntree Foundation, Transitions After 50 series, Bristol: Policy Press

White, J. (1999) Midwinter Spring: smart business and older workers. New Zealand guide to best practice for employers in an ageing population, Auckland: Equal Employment Opportunities Trust

Wood, G., M. Harcourt and S. Harcourt (2004) 'The effects of age discrimination on workplace practice: a New Zealand case study', Industrial Relations Journal, 35, pp.359-71

\section{IGPS and SoG Publications 2014}

\section{The New Zealand CPI at 100: History and Interpretation}

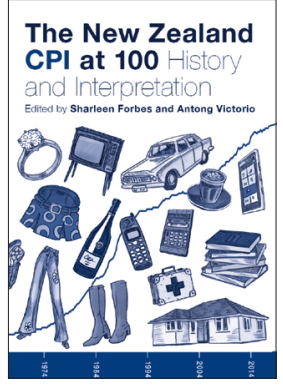

Edited by Sharleen Forbes and Antong Victorio
Very few New Zealanders have lives unaffected by the Consumers Price Index, or CPI. It is used by the New Zealand government to adjust student allowances, welfare benefits and superannuation; by the Reserve Bank to guide monetary policy; by the old Court of Arbitration, and also by employers and employees, to negotiate wages; and by the media to inform the public about the effects of price changes on their standard of living.

Some authors in this book document the New Zealand CPI as a history of conflicting machinations between unions, employers, public officials and lobby groups. Others view it as a mirror of domestic social norms and important international developments that eventually developed into a beacon with considerable public trust. Still others emphasise its technical evolution, from a crude selection of prices necessary for a just wage, to a modern indicator of consumer satisfaction and economic management.
A VUW Press Publication edited by Sharleen Forbes and Antong Victorio

Publication Date: July 2014. Format: A5 Paperback, pp 288

ISBN 978-0-864-73966-7 Price: \$40.00 (plus P\&P)

Place your order online at vup.victoria.ac.nz

VUW Press

49 Rawhiti Tce, Kelburn, Wellington, New Zealand

Phone: + 6444636580 Fax: + 644463 6581, Email: victoria-press@vuw.ac.nz

\section{The New Electoral Politics in New Zealand: The significance of the 2011 Election}

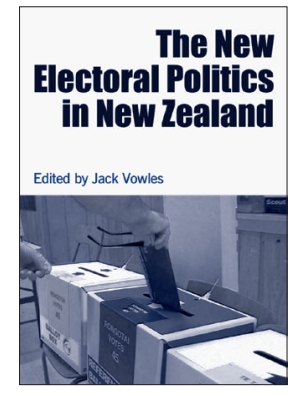

Edited by Jack Vowels
Around the world there was unusual interest in New Zealand's electoral politics during the 1990's, because of the country's adoption of the Mixed Member Proportional (MMP) electoral system. Since then international interest has lapsed. Yet at the 2011 election and concurrent referendum, New Zealanders voted to retain the MMP system. Among other inquiries, this book asks the question: why?

Looking back to the 2011 election and before, this book lays out the current state of the play in New Zealand electoral politics. Despite its reservations about MMP, the National Party has done very well under that system, particularly since 2005, with a vote share and polling that brought it well within reach of a single party majority in 2014 . For these reasons National appears unwilling to change the MMP system in ways recommended by an independent review conducted by the Electoral Commission. This book explores these questions, as well as others, including voter turnout decline, attitudes to welfare reform, women's representation, changes in Māori politics, and the growing importance of immigration on New Zealand politics and society.

An Institute for Governance and Policy Studies Publication edited by Jack Vowles Publication Date: May 2014. Format: A5 Paperback, pp 276 ISBN 978-0-475-12414-2. Price: \$39.95 (including P\&P within New Zealand) Place your order by phone or email. Preference is for payment via credit card, but invoices can be issued on request Institute for Governance and Policy Studies, Victoria University of Wellington Email igps@vuw.ac.nz Telephone +64 4463 6588, P0 Box 600, Wellington, New Zealand
VICTORIA 